\title{
The Acquisition of Pragmatic Competence in Indonesian Abroad Programs: The Importance of Informal Indonesian
}

\author{
Peter Suwarno* \\ Arizona State University, Tempe, Arizona, USA, 85281
}

\begin{abstract}
A B S T R A C T
This paper presents some comparisons between speeches of advanced learners of Indonesian with those of the native speakers, which indicates that many advanced learners do not communicate the way native speakers usually do. This can be attributed to the Indonesian language programs that focus mostly on teaching formal Indonesian grammar and vocabularies, neglecting informal conversational Indonesian which is essential for the acquisition of pragmatic competence. This paper discusses the importance of pragmatic competence in Indonesian language learning, including learning various speeches commonly used in daily interactions. Based on recordings of learners' interactions as well as notes on observations of teaching-learning activities in selected Indonesian abroad programs, this paper describes the challenges of developing pragmatic competence based on examples of learners' non-grammatical errors as well as inappropriate interactional uses of Indonesian. In addition, this paper will explain issues and challenges of achieving pragmatic competence in these programs and suggests possible solutions.
\end{abstract}

A R T I C L E I N F O

Paper Type:
Research Article
Article History:
Received 17 September 2018
Revised 1 October 2018
Accepted 9 October 2018
Keywords:
- Pragmatic competence
- Formal Indonesian grammar
- Informal conversation

Paper Type:

Article History:

Received 17 September 2018

Revised 1 October 2018

Accepted 9 October 2018

Keywords:

Pragmatic compe

- Informal conversation

\section{Introduction}

Many agree that Indonesian is one of the easiest foreign languages to learn ${ }^{1}$. This is especially true when learners move up their proficiency levels from novice to low intermediate. However, like most other languages, increasing proficiency once they are at the higher levels is challenging (Richards, 2008; Skehan, 1998; Yi, 2011). This applies to Indonesian language acquisition ${ }^{2}$ when moving up from low to high advanced that takes much longer and is challenging even during intensive abroad programs. Focusing on formal communicative fluency while emphasizing accuracy may lead to formal grammatical production, but may not lead to the ability to communicate the way native speakers do. Similarly, focusing on vocabulary building without considering various contexts used in real life communication or socio-cultural knowledge can lead to inappropriate language use in different contexts (Thornbury, 2007).

Formal Indonesian teaching ignores different types of forms commonly used in real life daily communication (Goebel, 2002), such as colloquial forms. This leads to pragmatic, non-grammatical errors that create a gap between speeches of Native Speaker (NS) and English speakers learning Indonesian at the advanced

\footnotetext{
*E-mail Addresses: peter.suwarno@asu.edu

${ }^{1}$ See language difficulty ranking in e.g.: https://www.atlasandboots.com/foreign-service-institute-language-difficulty/, or http://aboutworldlanguages.com/language-difficulty

${ }^{2}$ The discussion of proficiency levels in this paper follows the ACTFL guidelines which also confirm the difficulties in moving up once learners are at the higher levels as shown in ACTFL's description of inverted pyramid. See:

https://www.actfl.org/publications/guidelines-and-manuals/actfl-proficiency-guidelines-2012.
} 
levels (AL) speech during their interaction outside of class. Focusing only on grammatical and formal Indonesian impair learners' communicative skills in real life communication with NS.

This paper agrees with the widely-researched argument that learners' communicative skill does not depend solely on grammar and vocabulary achievements (e.g. Bardovi-Harlig \& Dornyei, 1998; Bardovi-Harlig \& Hardford, 1990, 1993), but learners must equip themselves with pragmatic competence through learning of various types of the target language used in various settings (e.g. Celce-Murcia, Dornyei, \& Thurrell, 1995). For this purpose, this paper provides two types of issues. First, AL that made positive transfers often produce grammatical constructions uncommonly used by NS. Second, AL that acquired formal Indonesian often failed to naturally interact with NS in daily interactional settings. Thus, it agrees with Sneddon's (2006) argument that the teaching of colloquial Indonesian is essential because the majority of speech events employ this type of Indonesian.

\section{Research Methods}

Due to the limited number of learners at the advanced levels, this study uses a combination of methodologies for collecting data, including notes and recorded observations in and outside of classes on learners' interaction with NS as well as interviews with learners and instructors. This study will use existing data from interviews, home works, learners' projects, and other activities that have been documented and/or recorded by the program staff and/or instructors. This study has selected and examined the Indonesian used only by the AL in the programs in the form of video materials and my notes as an instructor and/or resident or program director at the Consortium for the Teaching of Indonesian (COTI) program of 2008 in Salatiga, Indonesia, the Critical Language Scholarship (CLS) programs of 2010 until 2012 in Malang, Indonesia, as well as advanced classes at Arizona State University 2010 -2015. Selected written materials as well as video materials submitted by learners as part of projects or obtained from program staff were viewed, selected, transcribed, and examined not for their linguistic errors, but for the grammatically correct forms that are not commonly used by native speakers.

Notes on this data and years of my observation show that the majority of advanced Indonesian learners have, at least, some problems understanding NS speech in natural settings, which I believe is attributable to learning mainly prescribed Indonesian in formal classes. In various Indonesian classes in abroad programs, AL usually learn formal Indonesian even when these classes are intended to develop oral skill. Since the materials for conversation are significantly different from that practiced by ordinary Indonesians in daily conversational settings, when these students are actually engaged in real conversational native settings, their Indonesian differs from that of the NS. This discrepancy does not prevent AL from communicating with NS successfully, due to NS who usually tend to conform to the formal speech styles of AL.

For the purpose, I selected only conversation containing comparable utterances produced by both NS and AL from the same conversational speech events, such as a response to an inquiry or situation, request, or question. For example, at CLS Malang, I usually came early in the morning to observe students arriving and conversing with program staff or/and or conversation partners. Even toward the end of the two-month program when all participants and staff know each other well as good friends, the AL continued to use formal Indonesian in addressing all program staff and participants: "Selamat pagi. Apakabar?" (Good morning; How are you?), which in the same setting is rarely used by NS. Among NS themselves, they used other utterances, such as: "Eh gimana? (How goes it?), or used something related to the situation, such as: "Eh pak, baru datang? Macet ya?" (Just arrived? Caught in a traffic jam?). "Selamat pagi" (Good morning) is used in a polite and formal situation where respect is expected, but rarely among friends, especially in daily conversational speech events. However, due to the class learning habits and transfer from English, AL continued to use "Selamat pagi" to address someone even in casual speech situations where the NS usually do not.

\section{Results and Discussion}

\subsection{The importance of pragmatic competence in diglossic Indonesian communities}

Goebel (2002) and Sneddon (2006) argue that foreigners learning Indonesian should be aware of the fact that Indonesians do not always speak formal Indonesian which shows a social distance in formal domains but also colloquial Indonesian to show social intimacy in informal settings. The use of two types of Indonesian in two different domains has shaped Indonesian as a diglossic language (Charles Ferguson, 1959; Fishman, 1967). Following Fishman's (1967) description of diglossia, there are two major types of Indonesian used in different 
domains: the prestigious formal one $(\mathrm{H})$ and the colloquial one used in daily informal settings $(\mathrm{L})$. Formal Indonesian is not completely separate from the informal variant, since they exist on a continuum, ranging from the very informal to the very formal. Although the informal variant has been penetrating formal settings, Indonesians are still diglossic speakers, expected to be able to switch between the two types of speech. In fact, the ability to switch between formal and colloquial Indonesian is a necessary pragmatic skill for successful interaction in various Indonesian spheres (Sneddon, 2003 \& 2006).

It follows to argue that this diaglossic nature of Indonesian communities begs the teaching and learning of informal Indonesian to enhance learners' higher level communicative skills. Focusing only on formal Indonesian deprives learners of the nurturing needed to improve their pragmatic skills necessary for acquiring higher levels of proficiency (Goebel, 2002). Research on adult learners' pragmatic competence has not only shown convincingly the differences in the pragmatics of NS versus AL, but also that grammatical achievement does not necessarily translate into a similar level of pragmatic development (Bardovi-Harlig \& Hartford, 1990, 1993)

Pragmatics, according to Crystal (1985), is "the study of language from the point of view of users, especially of the choices they make, the constraints they encounter in using language in social interaction and the effects their language use has on other participants in the act of communication". Thus, it concerns communicative action in the language's socio-cultural context, which includes speech acts (e.g. requesting, apologizing, complementing, etc.) as well as engaging actively in communication using different types of speech styles and maintaining conversations in multifaceted speech events. What is important in pragmatics is the interpersonal relationship strategies an interlocutor uses as a social actor to get things done and accomplish his/her communicative goals (Leech, 1983). Pragmatic competence is an integral part of a AL's communicative competence that has to be treated as part of the acquisition of communicative skills (Savignon, 1991). After all, language learning is gaining not only knowledge about the target language, but also the ability to use the language in socially and culturally contextualized speech events (Bachman, 1990). That is why, it is essential that language learning is not just about gaining knowledge of communicative action, but how to put it into action in real life interaction in natural community settings. Pragmatic competence involves the ability to select accurately communicative acts and to use appropriate means to employ them according to the status of interactional negotiation (Fraser, 1990).

Following Bachman's (1990) model, it is clear that if the emphasis of foreign language teaching is equipping the learners to interact in different speech events, as well as to be able to communicate strategically to achieve their goals in various settings, then Indonesian teaching programs must include the teaching of daily conversational dialect. This is true, because the teaching of standard Indonesian only enhances the learners' capacity to write and interact in formal settings of professional relationship with respected interlocutors.

The problems of teaching pragmatic skills are not only attributable to the use of informal versus formal Indonesian, but in many cases also to the differences between grammatical utterances produced by learners versus NS. As shown in the examples of utterances made by AL in the example section below, the gap between NS and AL speech is also apparent in the differences between correct formal sentences commonly employed by NS versus $\mathrm{AL}^{3}$.

\subsection{Problems encountered by advanced Indonesian learners communicating with Indonesian NS}

Based on their mid-program evaluations, interviews, conversations with Resident Directors, and notes to Instructors, the following are comments from AL during the programs of COTI 2000 and 2008, CLS 2010 through 2012 regarding their interaction with native speakers.

a. "Why do host family members say: "Selamat pagi" (Good morning) and "Apakabar?" (How are you?) to me, but they never said it to each other?"

b. "I mostly understand them when they speak to me, but why don't I understand them when they speak Indonesian with each other?"

c. "They use formal Indonesian and speak clearly, when they interact with us, but among themselves, I am not sure which language they talk about?"

d. "Is this movie using real Indonesian? Why do I understand very little?"

e. "I think they speak very fast with each other."

\footnotetext{
${ }^{3}$ These advanced learners have been placed at least at the low advanced level based on the result of OPI tests conducted by Language Testing Internationals using ACTFL proficiency guidelines.
} 
f. "I am not sure they speak the language we learn in class."

g. "I think they mixed Indonesian with a local language."

h. "Do they use local variant of Indonesian? I got lost."

i. "They do not speak Indonesian; they speak Javanese."

j. "When they speak colloquial, I just listen and try to understand."

k. "They switch to formal Indonesian when speaking with me."

While there are cases where NS speak local languages $(\mathrm{g})$, the data collected here is based on domains where informal and conversational Indonesian was being used. Many linguistic features and pragmatic factors led to the ALs' comments on the challenges impacting their communication with NS, but, for the purpose of this study, only some of the most common ones from the collected data are presented. For example, in a recorded interaction occurring toward the end of a class when learners, instructors or conversation partners mingled and made plans for the rest of the day, the AL continued to use perfect formal Indonesian, but the NS produced different utterances shown below.
1) $\mathrm{AL}$
: Anda mau ke mana sesudah kelas ini? (Where are you going after this class?)
2) NS
3) AL2
: Mas James mau ke mana abis ni? (Where are you heading after this, James).
: pakah Anda mau minum kopi di starbuck dengan saya?
(Would you like to go and drink coffee in Starbuck with me?)
4) NS2
: Minum di J-Co aja, yuk? Yang deket. (Let's just get something to drink in J-Co, the close one)

The above utterances show that the $\operatorname{AL}(1 \& 3)$ used appropriate and grammatical utterances. A distinct feature of the AL speech above is that pronoun "Anda," a very handy translation of "you," and yes/no question marker "apakah" both respectable and formal, are rarely, if ever, used by NS in Indonesian daily conversation, but commonly used and taught in Indonesian classes. NS would only use "Anda" and "Apakah" to address people in formal and professional settings, and not in casual conversation. Even in formal settings, the use of "Anda" expresses a distant, non-personal, non-intimate and professional relationship, and thus, can sound less respectful in personal interaction. NS usually use proper names sometimes preceded with a term of address e.g. "Mas James" (2) (Brother James) or not using any pronoun at all (4). Similar wrong use of "Anda" occurred when accompanying AL and a program director (NS2) meeting a college Dean (NS1), where I noted the following conversation.
5) $\mathrm{AL}$
6) NS1
: "Apakah Anda sudah pernah ke Amerika?" (Have you been to America?)
7) NS2
: "Belum" (Not yet)
: “Kalau ke Australi sudah, kan pak?" (If to Australia, you have, haven’t you Sir?)

The use of "Anda" (5) is inappropriate, as it is formal but does not show respect in the speech situation; instead the AL should use "Bapak" (Mr.), "pak" (sir) (7) being used by the NS. In addition, the NS tend to use informal word "abis" (2) instead of the formal one "sesudah (2) (after). Note also that unlike AL, NS used the shorter form of some words: saja becoming aja (2), habis becoming abis (4).

On the yes/no questions, there is a persistent consistency of grammar that only NS used in all the recorded interaction, i.e. the use of negative marker at the end of the question. For example:
8) NSS
: Anda sudah makan? (Have you eaten?)
9) NS1 to AL : Sudah. Anda? (Lit: Have. You?)
10) NSS : Sudah.
11) NS1 to NS 2 : Dah makan, belum? (Alredy ate, not yet?)

Similar conversation occurred in another recording as follows:

12) NS1 to NS2 : Besok mau ikut, nggak? (Tomorrow (you) want to come along, not)

13) NS2 : Ikut dong. (Lit: Come along, of course)

14) NS1 to AL : Mas Joe mau ikut besok? (You (Joe) would like to come along?)

15) AL : Ya, saya mau ikut.

16) AL1 to NS3 : Apa Anda mau ikut juga? (Would you like to come along, too?)

Note that the NS used a yes/no question negative marker of "belum" (10) (not yet) and "nggak" (11) as the colloquial form of "tidak" (not), where the AL used the formal Indonesian using "apa" as yes/no question marker 
as commonly taught in Indonesian classes. Throughout all the recording of all the programs, I found no example of AL using this kind of informal form. What is interesting is that NS sometimes used "Anda" $(9,16)$ to AL, something NS never does to another NS, especially in a daily interaction among friends. This confirms that NS often adjusted to the speech of AL, instead of the other way around. It is also worth noting that AL can sometimes also use proper name (14), instead of "Anda," meaning some AL learned to avoid using "Anda."

In addition to interrogatives, AL and NS speeches also differ in responding to the same questions; they differ not only in terms of formality, but mostly due to the transfer of English into Indonesian, resulting in grammatical Indonesian utterances uncommonly produced by NS. The example below was taken from a recorded conversation about an inquiry of a missing book.

17) NS : Manabukunya? (Where is the book?)

18) $\mathrm{AL} \quad$ : Wah, saya sudah mengembalikan itu. (0, I have returned it)

When later an NS who earlier borrowed the book was asked the same question, he replied:

19) NS : Oh, dah dikembaliin. (Lit: 0 , it has been returned by me)

The AL has transferred the English active constructions into Indonesian (16) when NS in this context of discussing a known object usually uses the passive voice (17). The AL speech is grammatically correct and sounds formal, yet they sound unnatural or even inappropriate, because the use of active as opposed to passive voice can have different pragmatic ramifications as shown below. In a class recorded conversation, a teacher asked the students about turning in their homework.

20) NS : PRnya mana, ayo dikumpulkan! (Where is your homework, Lit: be turned in)

21) AL : Saya sudah mengerjakan PRnya, tapi saya meninggalkannya di rumah.

(I have done it, but Ileft it at home)

On a different subject a moment later, the teacher asked his co-teacher about an assignment that he was supposed to bring in that day.

22) NS : Tesnya sudah selesai? (Have you made the test?)

23) NS : : Sudah saya kerjakan, pak; tapi filenya ketinggalan di rumah.

(Lit: It has been done by me, but it was accidently left the file at home).

The difference between NS and AL lies in not only the AL using active voice versus NS using passive voice, but also the AL using active verb "meninggalkan" (affixes MEN-KAN) (19) means a deliberate action (which is not intended here), whereas the NS use of a type of passive verb "ketinggalan" (21) (prefix KE-AN) connotes an accidental or un-deliberate action (a strategic, useful, and commonly used response).

Using affix KE-AN may be complicated even for AL, but the tendency to use active when passive voice should be used is common among AL as shown recorded in a class exchange about a missing pen between a teacher (NS1), activity partner (NS2) and an advanced learner (AL) below.
24) NS1
: Di mana pena saya tadi? (Where is my pen?)
25) $\mathrm{AL}$
: Pak Amir pinjam itu. (Mr. Amir borrowed it)
26) NS2
: Dipinjam pak Amir. (Borrowed by Mr. Amir)

The use of active voice in (23) emphasizes the importance of the agent "Pak Amir" (Mr. Amir), while the use of passive voice suggests that the action of borrowing is more important than the agent (24), thus, putting the burden less on the doer. This positive transfer is common, where Indonesian NS tend to use passive constructions compared to English speakers (Baratta, 2009). Passive constructions are usually employed to avoid personal whims, show impersonality, and/or focus on the theme, i.e. the object/patient and verb/action rather than on subject/agent (Biber, 2004 \& Baratta, 2009).

Passive voice is also used in imperatives, such as in requests using "tolong" (please) and more commonly in negative imperatives using "jangan" (don't). A request to open the door, for example, the ALs' request is different from that of the NS. In the examples below, the NS tend to use passive voice (26), whereas the AL tend to use active voice (25).
27) $\mathrm{AL}$
: Tolong (mem)buka pintunya. (Please open the door)
28) NS
: Tolong dibuka (pintunya). (lit: Please (the door) be opened) 
In response to a person about to eat spoiled cake left on the office desk, AL employ active voice (27) as opposed to the passive voice used by NS (28).
29) $\mathrm{AL}$
: Jangan makan itu. (Don't eat it)
30) NS
: Jangan dimakan. (Lit: Don't be eaten)

These imperatives using active forms employed by AL or AL are not grammatically wrong; any NS would understand the speech perfectly. However, they do often sound unnatural to NS who do not express it that way. However, my observations also show that Indonesian instructors do not correct these kinds of unnatural responses.

Another feature commonly distinguishing NS from AL speech is the use of the suffix -NYA (lit: the, it and, a possessive pronoun) attached to a root-verb to refer to an action that has been completed, without mentioning the subject that has become the topic of the discussion, as shown in the following examples. In these examples, not only did the AL use active sentences, complete with the subject (and the objects if any), but they also missed the common NS practice of using -NYA attached to the verb, disregarding the subject (and the object). Note the differences between AL and NS utterances in complementing a student wearing a nice hat below:
31) AL1
32) AL2
33) NS
: Wah bagus topinya. (You have a nice hat.)
: Anda (mem)beli itu di mana? (Where did you buy it?)
: Bagus ya, beliNYA di mana? (Nice; Lit: Where was the buying)

Note that the use of subject for the active transitive verbs ("beli") (32) requires the object ("itu") (32) which NS does not use in this case, because the -NYA (32) takes care of the subject and object. AL also used utterances from that of NS in responding to someone's departure shown below:
34) NS
35) $\mathrm{AL}$
36) NS
: Pak Amin sudah berangkat ke Australi. (Mr. Amin has departed for Australia)
: Kapan Pak Amin berangkat? (When did Mr. Amin depart?)
: Kapan pulangNYA? (Lit: When is his coming back?

Following natural NS response (34), the AL response (33) should be "Kapan berangkatnya" (When is the/his departure). The use of active $(23,25,27)$, instead of passive $(24,26,28)$, voice as well as the lack of use of the pronoun -NYA ( $30 \& 33)$ shown in the examples above is commonly used by AL. Interviews with instructors who did not provide any corrections to these non-grammatical errors show that they are not very concerned about pragmatic competence, as shown in their comments below.
a) "There is nothing wrong with their sentences."
b) "They do not have to speak like us; sometimes we are informal."
c) "They don't make any grammatical mistake and any Indonesian understand them."
d) "If I say their responses were wrong, then I will have to give complicated explanations about colloquial Indonesian."
e) "As long as they speak well and there is no error, why not."
f) "It went well; I don't want to confuse them."
g) "I thought what is importance is to communicate well."

Unfamiliar with colloquial Indonesian, AL often find themselves in an uncomfortable situation when they communicate with Indonesian NS. In some situation Iobserved, NS often excluded the AL by switching into colloquial Indonesian. This next example was taken from recorded conversation of an advanced learner (AL) during a visit to a local market he was introduced by an activity partner to two ladies (NS). The conversation shows one of the major reasons for the discrepancies between NS and AL speech.
37) NS1
38) $\mathrm{AL}$
: "Kapan nyampenya Indonesia?" (When did you arrive in Indonesia?)
39) NS1
: "Maaf. Apa?" (Excuse me; what?)
40) NS2
"Kayaknya nggak ngerti, deh." (He doesn't seem to understand.)
41) NS2
: "Ya, iyalah .. kamu nanyaknya gitu sih?" (Of course, if you ask him that way.)
42) AL
"Kapan Anda sampai di Indonesia?" (When did you arrive in Indonesia?)
43) NS 1
: "Oh, dua hari yang lalu." (Two days ago.)
44) NS2
: "Coba tanyain mau nggak diajak main ke rumah!' (Try asking him if he would come to our house!)
45) $\mathrm{AL}$
: "Mau datang ke rumah saya?" (Would you come to my house?)
: "Ya, mungkin." (Yes, maybe). 
There are several informal forms employed by the NS above that makes it difficult for AL to understand. First, as mentioned above, there is no use of suffix -NYA by AL the way NS used it with a verb: "nyampekNYA" (37) or "nanyakNYA" (40). Second, instead of "sampai" (arrive), the nasalized colloquial form "nyampek' (37) (arrive) was used by the NS. Third, suffix -IN is used in place of either suffix -I or -KAN, i.e. "tanyaIN" (43) instead of "tanyaKAN." Fourth, shorter informal forms of the formal ones, e.g. "mengerti" becoming "ngerti" (39) "begitu" becoming "gitu" (38). Finally, choice and usage of vocabulary are different in formal and formal conversation; e.g. the NS informal use of the verb "main" (43) (play) was translated into a formal one "datang" (44) (come), just like the use of informal "abis" (2) instead of formal "sesudah" (1) (after). All these differences contributed a significant gap between AL and NS speech. Most, if not all, of informal conversational form is never integrated into the materials taught in advanced classes that I observed.

The ALs use perfect grammatical Indonesian, but sounds different from the NSs, such as shown in the recorded video conversation between an AL and NSs when an NS was looking for his key that was sucked in between cupboards. Note that the NS2 even encouraged the AL to use the formal form than the one commonly used for this occasion.
46) NS1
47) NS2
: Kuncinya dah ketemu? (Have you found the key)
48) $\mathrm{AL}$
: (busy trying to get the key out), Dah. (Found it)
49) N1
: Sudah menemukan ... tapi sulit mengambilnya dari situ (Have found it...but it's difficult to get it out of there)
50) $\mathrm{AL}$
51) NS2
52) $\mathrm{AL}$
: Kejepit, susah diambil. (Got stuck/pinned)
: Kejepit? (stucked)
: Terjepit; iya, bener; terjepit. (stuck, that's right stuck)
: Terjepit (got stuck).

In addition to the use of active by AL (48) instead of passive by the NS, there are cases where an attempt by AL to use informal form is encouraged by NS. In this example, above, however, the AL was encouraged to use "terjepit" (formal), and "kejepit" (informal).

As shown in the dialogue above the discrepancy not only led to the AL not understanding the NS colloquial Indonesian, but also the AL being excluded from the informal conversation.

However, the AL successfully communicated with NS, because the NS adjusted their speech styles for the AL, where the NS translated the informal speech into the formal version.

This kind of conversations commonly take place between advanced leaners and AL, characterized by the use of formal versus informal form, with AL unfamiliar with the informal one. The following section will discuss some of the major informal forms commonly used in daily conversations among NS that can be used to help learners of Indonesian advanced their daily conversational skills.

\subsection{Including informal Indonesian forms into the language teaching}

Urban colloquial or informal Indonesian was initially rooted in Jakarta native (Betawi) vernacular, which was shaped into modern Jakartan Indonesian by the younger generation. The rise of migration to Jakarta further formed the urban dialect of Indonesian with influences from foreign and local languages. The media and urban mobility helped popularize this Jakartan Indonesian, increasing the widespread use metropolitan youth speech styles colloquial Indonesian in oral communication throughout Indonesia (Snedon, 2003). Despite the negative perception of colloquial Indonesian that it is an inferior (L) variant considered unnecessary, corrupt, or a simplified version of standard Indonesian $(\mathrm{H})$, it is now widely used, such that, in formal communication where standard Indonesian was once expected, now more colloquial Indonesian is acceptable (Sneddon, 2006; SmithHefner, 2007).

Following Chomsky's (1965) idea, theoretical linguists claim that human language is characterized by "rulegoverned creativity", where the NS of a language possess a grammar, a mental system of elements and rules that allows them to form and interpret familiar and novel sentences, formal as well as colloquial. The grammar governs the articulation, perception, and patterning of speech sounds, the formation of words and sentences, and the interpretation of those sentences. To linguists, NS acquire languages and dialects, formal and colloquial, and follow similarly complex rules and grammars subconsciously.

\footnotetext{
${ }^{4}$ The NS in these cases are tutors or instructors in the abroad program whose responsibilities include to help improve the Indonesian of the ALs.
} 
The following are just some examples of colloquial Indonesian grammar and vocabulary ${ }^{5}$ to show that colloquial Indonesian used by NS in the example above is not an illogical and unsystematic language, and that it should not be too complicated to incorporate them into the teaching of Indonesian for different interactional settings.

The standard use of suffix $-K A N$ and suffix $-I$ can be complicated in Indonesian, because each gives different meaning and functions to the root verb to which it is attached. The colloquial Indonesian simplify this issues by using only suffix $-I N(41)$, which can have the function and meaning of either $K A N$ or $-I$, depending on the context. Teaching suffix $-I N$, commonly avoided by Indonesian instructors, actually makes the complex and confusing uses of suffix $-K A N$ and $-I$ simpler, because learners do not have to worry about the difference between $-K A N$ and $-I$. For example, "masukIN" can mean "masukKAN" (to put in, bring in) or "masukI" (to enter) which have different meanings. As Sneddon (2006) describes, this applies to many verbs including the followings, which instructors can include in their teaching activities.

Table 1. List of Suffixes in Informal and Standard Indonesian

\begin{tabular}{lll}
\hline Informal:Suffix $-I N$ & Standard:Suffix $-I$ & Standard: Suffix $-K A N$ \\
\hline deketin & dekati (approach, come near) & dekatkan (get s.t./s.o near) \\
ambilin & ambili (take repeatedly) & ambilkan (take s.t. for s.o.) \\
masukin & masuki (enter) & masukkan (put in; bring in) \\
\hline
\end{tabular}

In many cases, such as in examples (49-52) above, the Prefix TER- in standard Indonesian becomes the prefix $K E$ - in colloquial Indonesian (Sneddon, 2006:25), such as:

Table 2. List of Prefixes in Informal and Standard Indonesia

\begin{tabular}{ll}
\hline Informal,prefix KE- & Standard prefix TER- \\
\hline kejepit & terjepit $($ accidently pinned) \\
kebeli & terbeli (affordable) \\
ketuker & tertukar (accidently exchanged)
\end{tabular}

Perhaps, an informal form commonly used by NS (35 \& 38) rarely used by AL is the deletion and/or modification of the prefix $M E N$ - in the use of active transitive verbs. As shown below, this process to show informality has its rules and comprises a system that can be taught, i.e. instead of deleting the whole $M E N$ : prefix, it leaves the last nasal sound before the root verb (Sneddon, 2006: 20).

Table 3. Use of Prefix $M E N$ - in Standard and Informal Indonesia

\begin{tabular}{lll}
\hline Root verbs & Standard & Informal \\
\hline tunggu & Menunggu & nunggu (to wait for) \\
sampai & Sampai & nyampai/nyampek (to arrive) \\
cuci & Mencuci & nyuci (to wash) \\
\hline
\end{tabular}

As shown in the above examples, the NS frequently drop an initial sound or use a shorter form of some words, such as "abis" ((2), "aja" (4), "dah" (10), and "gitu" (38). This type of common processes of Indonesian colloquial forms include the following:

a. First initial letter or sound of (s) deletion: In this case, deleting the whole first syllable makes it very informal.

Table 4. Deletion Process of the First Syllable in Colloquial Indonesian

\begin{tabular}{lll}
\hline Standard & Informal & More informal \\
\hline sama & Ama & $m a$ (same, with) \\
saja & Aja & ja (just, only) \\
sudah & Udah & dah (have, already) \\
\hline
\end{tabular}

\footnotetext{
${ }^{5}$ For other resources of Colloquial Indonesian, consult the following articles by Tim Hassal (2012) at http://www.bahasakita.com/wpcontent/uploads/2012/11/Reading-Colloquial.pdf_and Uli Kozok (2008) at http://www.bahasakita.com/colloquial-urban-indonesian/
} 
b. First initial letter or sound of $/ \mathrm{h} /$ deletion:

Table 5. Deletion Process of Initial Letter or Sound of $/ \mathrm{h} /$

\begin{tabular}{ll}
\hline Standard & Informal \\
\hline hilang & ilang (lost) \\
hujan & ujan (test, exam) \\
hutang & utang (borrow money, debt) \\
\hline
\end{tabular}

Another informal form that should be easily taught to AL learners is a schwa Iə/ substitution of/a/that occurs at second syllable position (example 4). However, since this applies only to several words, learners need to learn when not to apply this rule. This form is very commonly used in conversational speech events.

Table 6. List of Schwa / $/$ / Substitution of /a/

\begin{tabular}{ll}
\hline Standard & Informal \\
\hline kejam & kejem (cruel) \\
hangat & anget (warm) \\
dekat & deket (near) \\
\hline
\end{tabular}

There are other informal forms, but the above examples are the most common ones that, based on the language use by NS in this study, help create the gap between AL and NS speech. With the rules and forms shown above, it is safe to argue that Indonesian courses and programs for AL at home and abroad that have mostly focused on formal Indonesian should now introduce colloquial Indonesian. For example, instead of using "dekat," the instructor can start introducing "deket', or instead of teaching the prefix $M E N$ - for use as an active marker, e.g. "mencuci," students should also learn to use the initial nasalized form "nyuci." It is also not complicated for the students to use the simple suffix $-I N$ in place of the complicated suffixes $-K A N$ and $-I$.

Obviously, NS also employ completely different colloquial words in informal conversations -- words that learners must learn to use appropriately as part of vocabulary building. In this case, instructors should also introduce colloquial vocabulary, such as the words "bilang," "mending", and "ngobrol," etc. In addition, the words that function as particles commonly used to mark informality that give emphasis and add emotion to the question, such as "dong" (12), "kek", "sih" (38), and "kok' (Sneddon, 2006: 118-130) .

More examples of informal forms can be incorporated into the teaching activities using simulated domains in class as well as in real life situations outside of class. This way, learners can experience exposure to real language use by NS in their daily conversations, enhancing their pragmatic competence.

The problem is that, instead of introducing informal forms of Indonesian, in several advanced classes I observed, the instructors prevented the students from using informal Indonesian. For example, an instructor who corrected the use of suffix $-I N$ in class conversations and asked that the students use the appropriate suffix $K A N$ or $-I$, commented: "We have been trying to teach them the complex use of $-I$ versus $-K A N$, and I am disappointed when they avoid this difficulty by using -IN." Although not all instructors who were interviewed disagreed with the teaching of informal Indonesian, a few clearly show their reluctance, as evidenced in their comments below:
a. "In class, we learn formal Indonesian; they can use informal forms outside of class."
b. "It sounds impolite and inappropriate to use informal Indonesian in class."
c. "It is safe to teach them formal Indonesian."
d. "Yes, they sound more polite and formal compared to Indonesians on the street. That is good."
e. "We do not want to teach them "bahasa gaul" (casual language); there is no clear rules, many irregularities, and the vocabulary is difficult to understand."
f. "We prepare them to be the speakers of proper Indonesian. They can learn the colloquial one themselves from the street."

\footnotetext{
${ }^{6}$ See Tim Hassal explanation on these "emotive participles" at http://www.bahasakita.com/emotive-particles-sih-deh-kok-dongcombination/ .
} 
g. "They have to learn the right, formal, and standard one first; they can learn the informal one latter by themselves in the community."

h. "We do not teach informal Indonesian to our young generations, why should we teach it to the foreigners?"

\subsection{The importance of colloquial Indonesian in the development of pragmatic skills}

Hassall's (2015) study shows that learners learn colloquial Indonesian from classmates who have been exposed to interactions with NS outside of class. Similarly, my interviews with returning Indonesian AL who speak some colloquial forms suggest that they learned them outside of class. Recognizing the importance of informal Indonesian and the possibility of integrating such forms into classroom activities, instructors should be encouraged to integrate informal Indonesian in class activities. By including this colloquial vocabulary, as well as grammatical features, instructors help enable the learners to successfully engage in natural native setting interactions, thus, enhancing the learners' pragmatic skills.

Teaching only formal Indonesian deprive students of the colloquial forms needed for pragmatic competence. Even AL may fail to comprehend or to convey desire intentions and politeness values (Bardovi-Harlig \& Dornyei, 1998); thus, increased pragmatic awareness should be an important goal of classroom activities (Bardovi-Harlig, 1996). Pragmatic exercises improve learners' communicative proficiencies (Bouton, 1994 \& Billmeyer, 1990). Pragmatic competence requires that foreign language teaching enable learners to communicate strategically to achieve their goals in various settings (Bachman's, 1990) including the informal one.

Teaching and learning as well as study and documentation of colloquial language are important for any nation or community, because colloquial language is a form of spontaneous expression of the self that constitutes the cultural identity of native speakers. Following Emmitt \& Pollock's (1997) suggestion that language is an important part of culture, teaching and learning a language must involve all aspects and varieties of language use in real daily interaction, where, at least in the case of Indonesian, informal language is crucially important.

The colloquial Indonesian has an important value and role for the knowledge of norms of interaction, politics, and power, as well as its benefit in accessing the natural world of Indonesian communities (Anderson, 1966). Despite its popularity in daily interaction, colloquial Indonesian is considered incorrect, inappropriate, impolite, or even degrading those who think this way do not realize that, as Burke (2000) suggested, there are two categories of colloquial language: the proper and the obscene; and that most colloquial Indonesian is informal but definitely not obscene. Instructors are encouraged to teach formal Indonesian due to their training to teach descriptive language, i.e. the language prescribed by grammarians, textbook writers and government planning agency. Many instructors lack awareness of the significance of informal or colloquial Indonesian as a descriptive type of language that naturally grows without formal agents deliberately attempting to shape the development of its systems or the direction of its changes. The challenge is, therefore, to convince Indonesian instructors that teaching colloquial Indonesian better represents and reflects the identity and culture of the Indonesian people than just a focus on the formal version of the language. It is not an exaggeration to suggest that anyone interested in understanding Indonesia should learn colloquial Indonesian.

This study is not without limits. The limited number of AL and programs that have AL makes it difficult to collect learners' non-grammatical errors. Some AL are familiar with and can use some colloquial forms more than others. More studies need to be done on factors affecting AL' success and failures in acquiring informal forms and in communicating with NS in variety of interactional settings.

\section{Conclusion}

This paper addresses the concern that it is very challenging to increase the proficiency of AL. It agrees with previous research that conventional efforts to focus on grammar and vocabulary do not further ALs' communicative proficiency, and that the problem lies in ignoring the gap between NS speech and ALs' speech.

The diglossic nature of Indonesian means that NS speak different types of Indonesian in formal domains versus in daily conversational events. This paper argues that the acquisition of informal Indonesian commonly used in daily interaction is essential for the achievement of pragmatic competence among ALs, enabling them to switch from formal to daily conversations the way Indonesian NS do, thus equipping the ALs with needed pragmatic skills for higher levels of proficiency. 
In addition to some common errors, this study's data show that learners use some formal and grammatical utterances that are rarely, if ever, used by NS, such as the use of formal standard affixation and the active voice when the NS would use informal affixation and the passive voice. Focusing on real grammatical errors, instructors do not correct these kinds of utterances that have non-grammatical errors usually attributable to positive transfer, because they are grammatically acceptable. This, I believe, leads to the AL feeling confidence in their sentences, leading to speaking grammatically but differently from NS. The recorded advanced Indonesian learners' interactions show they could not effectively interact with Indonesians in native settings using daily Indonesian. In this kind of NS and AL interaction, there is a phenomenon of speech accommodation (Giles, Mulac, Bradac, Johnson, 1987), but in the wrong direction, i.e. the NS conforming to the speech of the $\mathrm{AL}$, instead of the other way around. And, in some cases, the AL are excluded from NS interaction due to their use of informal Indonesian.

The differences between formal and informal Indonesian mostly lie in morphological grammar and a few vocabulary choices. The presented examples of rules and grammar in this paper provide insights regarding the ease in incorporating the teaching of informal Indonesian into class activities and in material development. Integrating informal Indonesian into Indonesian programs for AL not only equip the learners with pragmatic skills, but also provide knowledge and access to into Indonesian interactional norms, culture, and identity.

\section{References}

Anderson, B. R. O'G. (1966). The Languages of Indonesian Politics. Indonesia 1: 89.

Bachman, L. (1990). Fundamental considerations in language testing. Oxford: Oxford University Press.

Baratta, A. M. (2009). Revealing stance through passive voice. Journal of Pragmatics 41: 1406-1421.

Bardovi-Harlig, K., \& Hartford, B. (1990). Congruence in native and nonnative conversations: Status balance in the academic advising session. Language Learning, 40: 467-501.

Bardovi-Harlig, K., \& Hartford, B. (1993). Learning the rules of academic talk: A longitudinal study of pragmatic development. Studies in Second Language Acquisition, 15: 279-304.

Bardovi-Harlig, K. (1996). Pragmatics and language teaching: Bringing pragmatics and pedagogy together. In L. F. Bouton (Ed.), Pragmatics and Language Learning. 7: 21-39. Urbana, IL: University of Illinois at Urbana-Champaign.

Bardovi-Harlig, K., \& Dörnyei, Z. (1998). Do Language Learners Recognize Pragmatic Violations? Pragmatic Versus Grammatical Awareness in Instructed L2 Learning. TESOL Quarterly, 32/2: 233-262.

Biber, D. (2004). Historical patterns for the grammatical marking of stance. Journal of Historical Pragmatics 5/1:107-136.

Billmeyer, K. (1990). "I really like your lifestyle": ESL learners learning how to compliment. Penn Working Papers in Educational Linguistics, 6/2: 31-48.

Bouton, L. F. (1994). Conversational implicature in the second language: Learned slowly when not deliberately taught. Journal of Pragmatics, 22: 157-67.

Burke, D. (2000). The Slangman guide to street speak 1: The Complete Course in American Slang and Idioms. New York: Slangman Publishing.

Celce-Murcia, M., Dörnyei, Z., \& Thurrell, S. (1995). Communicative competence: A pedagogically motivated model with content specifications. In Issues in Applied Linguistics. 6/2: 5-35.

Chomsky, N. (1965). Aspects of the theory of syntax. Cambridge: The MIT Press.

Crystal, D. (1985). A dictionary of linguistics and phonetics. 2nd. edition. Oxford: Blackwell.

Emmitt, M., \& Pollock, J. (1997). Language and Learning: An introduction for teaching. $2^{\text {nd }}$ edition. Oxford University Press.

Ferguson, C. (1959). "Diglossia". Word, 15/2: 325-340.

Fishman, J. (1967). Bilingualism with and without diglossia; diglossia with and without bilingualism. Journal of Social Issues, 23/2: 29-38.

Fraser, B. (1990). Perspectives on politeness. Journal of Pragmatics, 14, 219-236.

Giles, H., Mulac, A., Bradac, J. J., \& Johnston, P. (1987). Speech accommodation theory: The first decade and beyond. In M. L. McLaughlin (Ed.), Communication Yearbook (13-48). Beverly Hills, CA: Sage Publication

Goebel, Z. (2002). When do Indonesian speak Indonesian? Some evidence from inter-ethnic and foreignerIndonesian interaction and its pedagogic implication. Journal of Multilingual and Multicultural Development, 23/6: 479-489 (Published online: 29 Mar 2010). 
Hassall, T. (2015). Influence of fellow L2 learners on pragmatic development during study abroad. Intercultural Pragmatics, 12/4: 415-442.

Leech, G. (1983). Principles of pragmatics. London: Longman.

Richards, J. C. (2008). Moving beyond the plateau: From intermediate to advanced levels in language learning. New York: Cambridge University Press.

Savignon, S. (1991). Communicative language teaching: State of the art. TESOL Quarterly, 25:261-277.

Skehan, P. (1998). A cognitive approach to language learning. Oxford: Oxford University Press.

Smith-Hefner, N. J. (2007). Youth language, gaul sociability, and the new Indonesian middle class. Journal of Linguistic Anthropology. 17/2:184-203.

Sneddon, J.N. (2003). Diglossia in Indonesian. Bijdragen tot de Taai-Land-en Volkenkunde 159/4: 519549.

Sneddon, J.N. (2006). Colloquial Jakartan Indonesian. Canbera: Pacific Linguistics, The Australian National University.

Thornbury, S. (2007). How to teach speaking. Harlow: Pearson Education Limited.

Yi, F. (2011). Plateau of EFL learning: A psycholinguistic and pedagogical study. Available online at wlkc. nbu. edu. cn/jpkc\% 5Fnbu/daxueyingyu/download/014. pdf. Retrieved January 21, 2018. 